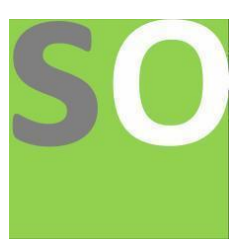

Article title: Misleading Advertisement and its regulation in the EU Medicine Promotion legal framework Authors: Adewale Lawrence[1]

Affiliations: Northeastern University College of Professional Studies[1]

Orcid ids: 0000-0001-6459-8011[1]

Contact e-mail: lawrence.ad@northeastern.edu

License information: This work has been published open access under Creative Commons Attribution License $\mathrm{http}: / / c r e a t i v e c o m m o n s . o r g / l i c e n s e s / b y / 4.0 /$, which permits unrestricted use, distribution, and reproduction in any medium, provided the original work is properly cited. Conditions, terms of use and publishing policy can be found at https://www.scienceopen.com/.

Preprint statement: This article is a preprint and has not been peer-reviewed, under consideration and submitted to ScienceOpen Preprints for open peer review.

DOI: 10.14293/S2199-1006.1.SOR-.PPQWI00.v1

Preprint first posted online: 20 July 2021

Keywords: Medicine promotion, Advertisement of new drug, New drugs marketing, EU regulation of medicine, Pharmaceutical, new drugs regulation, pharmaceutical drug promotion, marketing new drugs, EU new medicine, rules for promoting new drugs 


\section{Misleading Advertisement and it's regulation in the EU Medicine Promotion legal framework.}

\section{Background and Introduction}

Promotion of medicine is "any activity undertaken by a pharmaceutical company or with its authority which promotes the administration, consumption, prescription, purchase,

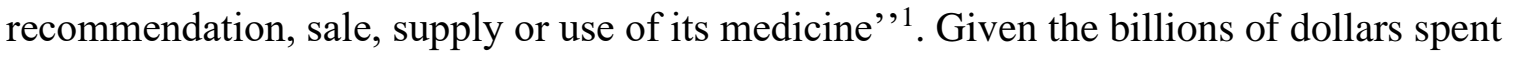
during drug development, a pharmaceutical company must be able to make a profit in order to sustain its self, as such, good promotion strategy to market the product is paramount to the success of the company. The promotion of medicine might take several forms, such as journal and direct mail advertising, activities of representatives, the supply of samples, provision of inducements within the legal framework, provision of hospitality for promotional purposes, sponsorship of promotional or scientific meetings and other sales promotion in whatever form ${ }^{1}$.

Advertising of medicine is acceptable as long as it follows the standards of practice ${ }^{2}$. According to the UK MHRA, the "society demands that advertising of any commodity, service or anything that may be of interest to the consumer, should be of a high standard and should not include anything that could cause serious or widespread offence, create unrealistic expectations in the consumer or be misleading" ${ }^{\prime 2}$. The European Union (EU) has a harmonized European Community (EC) policy on medicine advertisement with legislation and code of conduct as incorporated in the principles set out in the WHO Ethical Criteria for Medicinal Drug Promotion, the IFPMA code of practice, the EFPIA Code of Promotion on Prescription-Only Medicines, and Directive 2001/83/EC on the community code relating to

\footnotetext{
${ }^{1}$ PMCPA, 2019. The ABPI code of practice for Pharmaceutical Industry. Provisions of the code of practice, Clause 1: Scope of the code and Definition of Certain Terms. https://www.pmcpa.org.uk/media/2258/code-ofpractice-2019.pdf

${ }^{2}$ MHRA, 2019. The Blue Guide, third edition: Advertising and Promotion of Medicines in the UK. https://assets.publishing.service.gov.uk/government/uploads/system/uploads/attachment_data/file/824778/ Blue_Guide.pdf
} 
medicinal products for human use, as amended by Directive 2004/27/EC ${ }^{3}$. Aside from the European legislation on advertising, each Member State also has national bodies responsible for the monitoring and enforcement to ensure compliance with the rules ${ }^{2}$. For example, the United Kingdom MHRA uses both its national and European legislation to monitor advertising activities in the $\mathrm{UK}^{2}$.

\section{The legal framework of Medicine Advertisement in the EU}

The relevant European legislation on advertising is contained in Titles VIII and VIIIa of European Directive 2001/83/EC as amended ${ }^{2}$; which is the Community Code relating to medicinal products for human $u^{2} \mathrm{e}^{2}$. It contains rules on the content of advertising and promotions and requirements for national monitoring by each Member States ${ }^{2}$. Although the term 'advertisement' was defined rather broadly in regulation 7 of the Regulations, it reflects the definition of "advertising of medicinal products" at article 86 of Directive 2001/83/EC, which introduces the important concept of activities "designed to promote the prescription, supply, sale or consumption of medicinal products"2 ${ }^{\text {. According to the directive }}{ }^{4}$, advertising a medicinal product is not allowed if:

1. the medicinal product has not been granted a marketing authorization;

2. not compatible with the information listed in the summary of the product's characteristics;

3. not encourage the rational administration of the medicinal product;

4. misleading, within the meaning of Council Directive.

\footnotetext{
${ }^{3}$ Gary T. Ford (1993) ,"Regulation of Advertising in the European Community: an Overview", in E - European Advances in Consumer Research Volume 1, eds. W. Fred Van Raaij and Gary J. Bamossy, Provo, UT : Association for Consumer Research, Pages: 559-564. https://www.acrwebsite.org/volumes/11635/volumes/e01/E-01

${ }^{4}$ EUR-Lex, 2005. Directive 2005/29/EC of EU Parliament: Unfair Commercial Practices Directive. https://eurlex.europa.eu/legal-content/EN/TXT/?uri=CELEX\%3A32005L0029\&qid=1607265307184
} 
For this final paper, I will focus on the fourth part, misleading advertisement, and analyze cases of misleading advertising in the EU.

\section{Misleading Advertisement}

According to the Directive 2005/29/EC of the European Parliament and the Council concerning unfair business-to-consumer commercial practices, there are two types of unfair commercial practices, namely, misleading commercial and aggressive commercial practices ${ }^{5}$. These two practices are generally prohibited ${ }^{5}$. Misleading commercial practices include "misleading advertising, which by deceiving the consumer prevent him/her from making an informed and thus efficient choice, ${ }^{, 5}$. Misleading practices could be either misleading actions or misleading omissions ${ }^{5}$.

Misleading advertisement is defined "as any advertising which in any way, including its presentation, deceives or is likely to deceive the persons to whom it is addressed or whom it reaches and which, by reason of its deceptive nature, is likely to affect their economic behaviour or which, for those reasons, injures or is likely to injure a competitor", ${ }^{\text {. As }}$ outlined, misleading advertising, not only influence the consumer's behaviour but can also have a negative implication on the market by limiting product competition and reducing choice for patients ${ }^{7}$. However, to determine if an advertisement is misleading, the European Union Directive 2005/29/EC, says that the following should be considered:

\footnotetext{
${ }^{5}$ EUR-Lex, 2005. Directive 2005/29/EC of the European Parliament and of the Council of 11 May 2005 concerning unfair business-to-consumer commercial practices in the internal market and amending Council Directive 84/450/EEC, Directives 97/7/EC, 98/27/EC and 2002/65/EC of the European Parliament and of the Council and Regulation (EC) No 2006/2004 of the European Parliament and of the Council ('Unfair Commercial Practices Directive'). OJ L 149, 11.6.2005, p. 22-39. https://eur-lex.europa.eu/eli/dir/2005/29/oj

${ }^{6}$ EUR-Lex, 2006. Directive 2006/114/EC of the European Parliament and of the Council of 11 Dec 2006 concerning misleading and comparative advertising. https://eur-lex.europa.eu/legalcontent/EN/TXT/?uri=celex\%3A32006L0114

${ }^{7}$ European Commission, 2019. Competition Enforcement in the Pharmaceutical Sector (2009-2017). https://ec.europa.eu/competition/publications/reports/kd0718081enn.pdf
} 
(a) the characteristics of goods or services, such as their availability, nature, execution, composition, method and date of manufacture or provision, fitness for purpose, use, quantity, specification, geographical or commercial origin or the results to be expected from their use, or the results and material features of tests or checks carried out on the goods or services;

(b) the price or the manner in which the price is calculated, and the conditions on which the goods are supplied or the services provided;

(c) the nature, attributes and rights of the advertiser, such as his identity and assets, his qualifications and ownership of industrial, commercial or intellectual property rights or his awards and distinctions.

Misleading advertisement is detrimental to patients, the company itself and the pharmaceutical industry as it will increase distrust among the patient population, incur financial burden for the companies involved while undermining ethical principles and code of practice for safer patient care and treatment.

\section{Cases of Misleading Advertisement in Europe}

\section{Case \#1: Verband Sozialer Wettbewerb eV v. TofuTown.com GmbH (Case C-422/16)}

Case C-422/16, Verband Sozialer Wettbewerb eV v. TofuTown.com $\mathrm{GmbH}^{8}$, was between the German consumer protection group Verband Sozialer Wettbewerb (VSW) and TofuTown ${ }^{8}$. VSW is a German association whose responsibilities include combatting unfair competition $^{8}$ while TofuTown is a German Food company ${ }^{9}$, which produces and distributes vegetarian/vegan foodstuffs ${ }^{8}$. It promotes and distributes, among others, pure plant-based products under the designations 'Soyatoo tofu butter', Plantcheese, 'Veggie Cheese', 'Cream'

\footnotetext{
8 Judgement of 14 June 2017, Verband Sozialer Wettbewerb eV v TofuTown.com GmbH, C-422/16, EU:C:2017:458

${ }^{9}$ TofuTown, 2020. Home of your veggie foods. https://www.tofutown.com/
} 
and other similar designations ${ }^{8}$. According to the court case, TofuTown marketed its pure plant-based products using designations such as cheese and butter, even though the products were not from mammary secretions or milk, but that they added a description to each of their product to clarify the content.

The Claimant, VSW, filed a case of a prohibitory injunction against TofuTown at the European Union Court of Justice, Landgericht Trier (Regional Court, Trier, Germany) ${ }^{8}$, in 2017. VSW argued that the use of the terms 'cheese' or 'butter' for their pure plant-based product, even though they were not made from milk, "constitutes an infringement of unfair competition law by violating Article 78 of the EU Regulation No. 1308 / 2013 establishing a common organization of the markets in agricultural products" ${ }^{\prime 10}$. According to this Regulation and its Annexes, "the designation 'milk' means an animal product gained from a milking process, and the milk products designated in the Annex such as cheese and butter are exclusively derived from milk, and it is prohibited to use such designations for plant-based products $" 10$. VSW argued that the use of such terms would confuse the consumers and misled them to believe that it has a diary milk origin. VSW, in its argument, relied on the infringement of Paragraph 3a of the Law on Unfair Competition, in conjunction with Annex VII, Part III, points 1 and 2, and Article 78 of Regulation No 1308/2013 ${ }^{8}$, “which precludes the use of the term 'milk' and the designations reserved by that Regulation for the designation of a plant-based product in marketing or advertising, even if those terms are expanded upon by clarifying or descriptive terms indicating the plant origin of the product at issue ${ }^{, 10}$.

TofuTown disagreed with VSW and argued that the advertisement did not infringe the EU law as over the years, their consumers are familiar with the product content in addition to

\footnotetext{
${ }^{10} \mathrm{CMS}$ Law, 2017. Publication: Misleading representations of new "designer food". https://cms.law/en/int/publication/misleading-representations-of-new-designer-food
} 
the added descriptive label packaging. They further expressed that their customers were not misled because their products' plant origins were clear ${ }^{11}$.

The National Court, Landgericht Trier, examined the case in reference to Regulation No 1308/2013, which was the most recent iteration of a 1987 regulation, (EEC) No 1898/87, on 'the protection of designations used in the marketing of milk and milk products,' and is part of a complex set of EU rules, which have the express purposes of protecting the dairy industry and promoting the consumption of dairy in the $\mathrm{EU}^{12}$. The Regulation precludes the use of a set of words for the naming or marketing of any products which are not made from 'mammary secretions' ${ }^{12}$. The court further referred to the judgment of 16 December 1999, $U D L(C-101 / 98, E U: C: 1999: 615)$, in which the Court of Justice held essentially that Regulation No 1898/87 precluded the use of the description 'cheese' for products in which the milk fat has been replaced by vegetable fat, even if that description is complemented by additional descriptive material ${ }^{8}$. The court affirmed that Part III of Annex VII to Regulation No 1308/2013 relates to milk and milk products and that according to Part III, point 1, first subparagraph, states that the term 'milk' means 'exclusively the normal mammary secretion obtained from one or more milkings without either addition thereto or extraction therefrom'8.

The court decided that it was clear that the term 'milk' cannot, in principle, be lawfully used to designate a purely plant-based product, since milk is, within the meaning of that provision, 'an animal product ${ }^{\prime}$. They also added that clarifying or the addition of descriptive term did not fall within the terms which may be used with the designation 'milk,' under point 1, second subparagraph (b) of the Annex since the alterations to the composition

\footnotetext{
${ }^{11}$ BBC News, 2017. EU court bans dairy-style names for soya and tofu. https://www.bbc.co.uk/news/business40274645\#: :text=Plant\%2Dbased\%20foods\%20cannot\%20be,involving\%20German\%20food\%20company\%20 TofuTown.

12 B. Bolton, 2017. The TofuTown Decision: What does dairy's monopoly on words mean for plant-based businesses in the UK? https://www.lexology.com/library/detail.aspx?g=5229937c-2a93-43088ee6-b71c5ebbb0a9
} 
of milk that the additional words may designate under that provision are those which are limited to the addition and/or subtraction of its natural constituents, which does not include a total replacement of milk by a purely plant-based product ${ }^{8}$.

\section{Case \#2: Bundesverband der Verbraucherzentralen und Verbraucherverbände -}

Verbraucherzentrale Bundesverband e.V. (BVV) v Teekanne GmbH \& Co. KG (Teekanne)

\section{(Case C-195/14)}

The European Court of Justice (ECJ) made a judgement on the BVV v. Teekanne case initially on 4 June 2014, when they ruled that "it is unlawful to use a package design for a fruit tea that gives the impression that an ingredient is present when it is not, in fact, present, and this is apparent solely from the list of ingredients on the fruit tea's packaging" ${ }^{13}$. Teekanne appealed the case, and ECJ reviewed the case again on 04 June 2015.

BVV v. Teekanne, Case C-195/14 ${ }^{14}$ was between Teekanne, a German Fruit-Tea company and BVV, a German consumer-protection association ${ }^{14}$. Teekanne marketed a fruit tea called 'Felix Himbeer-Vanille Abenteuer' ('Felix raspberry and vanilla adventure') ${ }^{15}$. The packaging comprises in particular depictions of raspberries and vanilla flowers and the indications 'Früchtetee mit natürlichen aromen' ('fruit tea with natural flavourings') and 'Früchtetee mit natürlichen aromen - Himbeer-Vanille-Geschmack' ('fruit tea with natural flavourings - raspberry-vanilla taste' $)^{15}$. Of note, the fruit tea did not contain raspberries or vanilla, only that it tasted like raspberries and vanilla. BVV argued that "Teekanne's packaging misled consumers with regards to the content of the tea, as the expectation would

\footnotetext{
${ }^{13}$ King \& Spalding, 2016. Court of Justice of the European Union: Ruling on Package Design of Foodstuffs (Teekanne Felix). https://www.jdsupra.com/legalnews/court-of-justice-of-the-europeanunion-42067/

14 Judgement of 04 June 2015, Bundesverband der Verbraucherzentralen und Verbraucherverbände Verbraucherzentrale Bundesverband e.V. v Teekanne GmbH \& Co. KG, C-195/14, EU:C:2015:361 ${ }^{15}$ Court of Justice of the European Union, 2015. Press release: The labelling of a foodstuff must not mislead the consumer by giving the impression that a particular ingredient is present, even though it is not in fact Present. https://curia.europa.eu/jcms/upload/docs/application/pdf/2015-06/cp150064en.pdf
} 
be that the fruit tea would contain vanilla and raspberry or at least natural vanilla flavoring and natural raspberry flavoring, ${ }^{\prime 13}$. Teekanne argued that consumers were not misled since it is clear from the fruit tea's list of ingredients, which is printed on the packaging, that the flavorings in the product have the taste of raspberry or vanilla ${ }^{13}$. To support Teekanne's case, the label description, as indicated by Teekanne, was expressed, in a manner free from doubt, the fact that the flavorings used are not obtained from vanilla and raspberries but only taste like them ${ }^{13}$.

The ECJ ruled that according to Articles 2 (1) (a) (i) and 3 (1) (2) of Directive $2000 / 13$, it is required that "the consumer has correct, neutral, and objective information that does not mislead him or her, and that the labeling of food cannot mislead" ${ }^{\prime 13}$. The court acknowledged that for some consumers, the purchasing decision might be based on the product's composition, which could be found on the descriptive product label as expressed by Teekanne but that "it does not in itself exclude the possibility that the design of the packaging may otherwise mislead the consumer when some of the items on the labeling are erroneous, ambiguous, contradictory or incomprehensible",13.

According to the judgement on 04 June 2015, "the ECJ upheld that in case some of the items on the packaging are misleading, erroneous, ambiguous, contradictory or incomprehensible, then a correct and comprehensive list of ingredients may not be capable of sufficiently correcting the consumer's erroneous or misleading impression concerning the characteristics of a foodstuff that stems from the other items comprising its labeling" 16 .

\footnotetext{
${ }^{16}$ Carbonnelle et al, 2015. Belgium: Misleading appearances are not the Court of Justice's cup of tea. https://www.twobirds.com/en/news/articles/2015/global/food-law-jul/belgium-misleading-appearances-arenot-the-court-of-justices-cup-of-tea
} 


\section{Case \#3: F. Hoffmann-La Roche Ltd and Others v. Autorità Garante della Concorrenza e}

\section{del Mercato (Case C-179/16)}

The case (Case C-179/16) ${ }^{17}$ was about the agreement between the pharmaceutical groups Roche and Novartis designed to reduce the use of Avastin in ophthalmology and to increase the use of Lucentis ${ }^{18}$. Avastin and Lucentis are medicinal products developed by Genentech, a company which belongs to the Roche group ${ }^{18}$. Genentech entrusted the commercial exploitation of Lucentis to the Novartis group by way of a licensing agreement, but Roche markets Avastin ${ }^{18}$. Roche is the Italian subsidiary of F. Hoffmann-La Roche Ltd, while Genetech is the US subsidiary of Roche ${ }^{19}$. Through its US subsidiary Genentech, Roche developed two medicines from related active substances ${ }^{19}$. The first, Avastin ${ }^{\circledR}$ (bevacizumab), was granted marketing authorization (MA) for an oncological indication ${ }^{19}$. The second, Lucentis ${ }^{\circledR}$ (ranibizumab), was developed later and was granted an MA specifically for the treatment of ophthalmological conditions such as macular degeneration and glaucoma ${ }^{19}$. A practice developed off-label, whereby doctors prescribed Avastin ${ }^{\circledR}$ for the treatment of eye conditions ${ }^{19}$. The Italian health authority permitted and later encouraged, this 'off-label' use, even after Lucentis ${ }^{\circledR}$ had received its MA and obtained reimbursement for that indication ${ }^{19}$. Novartis licensed Lucentis ${ }^{\circledR}$ from Genentech and owns a $33 \%$ share in Roche itself ${ }^{19}$.

In 2014, the Italian competition authority found that Roche and Novartis had colluded to discourage the off-label use of Avastin® and had a common interest in generating a higher

\footnotetext{
17 Judgement of 23 January 2018, F. Hoffmann-La Roche Ltd and Others v. Autorità Garante della Concorrenza e del Mercato, C-179/16, EU:C:2018:25

${ }^{18}$ Court of Justice of the European Union, 2018. Press release: The agreement between the pharmaceutical groups Roche and Novartis designed to reduce the use of Avastin in ophthalmology and to increase the use of Lucentis might constitute a restriction of competition 'by object'. https://avukati.org/wpcontent/uploads/2017/08/CP180006EN.pdf

${ }^{19}$ Van Bael \& Bellis, 2018. Case C-179/16 F. Hoffmann-La Roche and Novartis. https://www.vbb.com/media/Insights_Articles/2018.01.24_HLR_Avastin.pdf
} 
volume of sales of the more expensive Lucentis ${ }^{19}{ }^{19}$. The Italian authority considered this as an unlawful market-sharing agreement and therefore a serious restriction of competition by object, contrary to Article $101 \mathrm{TFEU}^{19}$. As a result, the companies were fined approximately $€ 90$ million each ${ }^{19}$. Both companies appealed to the Italian courts and the Italian Council of State, which asked the ECJ for guidance ${ }^{19}$ as they both argued that the safety profile of Avastin's off-label use was central to their decision and action.

The ECJ affirmed that the joint efforts of Novartis and Roche to communicate that the off-label use of a product is less safe than the on-label use of another product could be considered a restriction of competition "by object"19. It was apparent that both companies disseminate adverse information about Avastin ${ }^{\circledR}$ to reduce competition. The ECJ further added that the sole responsibility to disseminate information about the off-label use of a product lies with the Marketing Authorization Holder ${ }^{19}$. As such, it was the court's finding that the dissemination of misleading information relating to to the adverse reactions due to the medicinal products in order to reduce competition constitutes a restriction of competition under Article 101(1) of the TFEU ${ }^{20}$.

\section{Summary}

Case C-422/16 between TofuTown and the German Consumer Protection Group VSM showed how the wrong labeling on a product could be tantamount to misleading advertising. Misleading advertising is prohibited generally in the EU as it undermines transparency and consumers trust. Consumers might be made to believe that the composition of the veggie food product contains milk given the labelling, although TofuTown argued that the consumer's knowledge of their product in addition to the descriptive labelling should help clarify that it was not a misleading attempt. However, the ECJ upheld their decision and

\footnotetext{
${ }^{20}$ David Mahoney, 2020. RA 6204 Lecture Note: Legal Issues in International Food, Drug and Medical Device Regulation: Case C-718/15, PTC Therapeutics International Ltd. v. EMA (2018) ECLI:EU:C:2018:66.
} 
affirm that plant-based products should not be labelled as mammillary milk product, regardless of the addition of label description. Similarly, the BVV and Teekanne case (Case C-195/14) showed the use of product description that does not align with the product composition. Teekanne marketed his fruit tea product with a description that might suggest that it contained raspberries and vanilla flowers. The ECJ ruled that the labeling is misleading as the product only tasted like raspberries and Vanilla flower.

Finally, Roche Group with Novartis, Case C-179/16, showed yet another misleading attempt to increase the sales of their expensive Lucentis product by exaggerating the adverse effect of the off-label use of Avastin.

\section{Conclusion}

Misleading advertisement either through action, by giving false information, or by omission, in the case of leaving out important information, amount to unfair commercial practices. In the EU, the Unfair Commercial Practices Directive (UCPD) and the Misleading and Comparative Advertising Directive (MCAD) both address misleading advertising in the context of the Single Market ${ }^{21}$. These codes are in place to promote transparency, honesty and truthfulness. As seen, in the cases outlined above, there are consequences for such practices in terms of distrust among the consumers, liability for the companies with legal implications, such as civil or criminal prosecution. It also as the tendency to reduce product competition, thereby limiting consumers options.

To avoid misleading advertising, companies must adhere strictly to the rules and regulation with proper oversight to ensure compliance.

\footnotetext{
${ }^{21}$ Alliance, 2020. Misleading Advertising. https://www.easa-alliance.org/issues/misleading-advertising
} 